This item was submitted to Loughborough's Research Repository by the author.

Items in Figshare are protected by copyright, with all rights reserved, unless otherwise indicated.

\title{
Idealism, realism, and immigration: David Miller's Strangers in Our Midst
}

PLEASE CITE THE PUBLISHED VERSION

http://dx.doi.org/10.1080/13698230.2016.1231678

\section{PUBLISHER}

(C) Taylor \& Francis

\section{VERSION}

AM (Accepted Manuscript)

\section{PUBLISHER STATEMENT}

This work is made available according to the conditions of the Creative Commons Attribution-NonCommercialNoDerivatives 4.0 International (CC BY-NC-ND 4.0) licence. Full details of this licence are available at: https://creativecommons.org/licenses/by-nc-nd/4.0/

\section{LICENCE}

CC BY-NC-ND 4.0

\section{REPOSITORY RECORD}

Parvin, Phil. 2019. "Idealism, Realism, and Immigration: David Miller's Strangers in Our Midst". figshare. https://hdl.handle.net/2134/22564. 
Idealism, Realism, and Immigration: David Miller's Strangers in our Midst

Phil Parvin ${ }^{*}$

Department of Politics, History, and International Relations, Loughborough University

\section{Abstract}

David Miller's Strangers in our Midst is an important contribution to the debate among political philosophers about how liberal democratic states should deal with the issue of migration. But it is also a thoughtful statement concerning how best to do political philosophy and, as such, contributes also to the growing debate within Anglo-American political theory about the relative merits of 'ideal' versus 'non-ideal' normative theorising. Miller's argument in the book builds on his earlier published work in suggesting that political philosophy should be 'for Earthlings': it should not be understood as a process of ideal theorising which ignores political reality. He argues that normative theorists should seek to resolve complex political problems by taking seriously the political context that makes these problems complex, rather than putting aside that context in the interests of deriving first principles. This is a controversial approach, which requires political philosophers to take more seriously than they often do the expressed concerns of citizens living in democratic states and the practical problems associated with applying normative principles in ways which actually help address the issue at hand. This piece discusses some of these themes, and the issue of migration more generally, in order to help frame the debate which follows.

Keywords: Migration, ideal theory, realism, non-ideal theory, justice, borders, multiculturalism. 
In the time that it takes you to read the articles in this special section on David Miller's Strangers in our Midst, assuming that it takes you around four hours, around 6000 men, women, and children across the world will have been forced to flee their homes for fear of violence. That is around 1440 people per hour, or 24 people a minute, or, if you prefer, 4 people in the time it took you to read that first sentence. $21.3 \mathrm{~m}$ people were registered as refugees by the UN in 2015, although the number of people seeking refuge in countries other than their own has been estimated to be much higher (UNHCR, 2016). Of those that we know about, $4.9 \mathrm{~m}$ crossed one of Syria's borders in the hope of escaping the brutal civil war that has devastated the region and left $12 \%$ of its citizen population dead or injured (United Nations, 2015). Many others who left or tried to leave will not show up in this figure. Some will have destroyed their papers on the way for fear of being turned back. Others will have paid people smugglers for the opportunity to cram themselves and their families onto boats for illegal passage from Turkey to Greece. Others will have taken a different way out, perhaps travelling on foot through central Europe to Germany from Turkey, or joining with refugees fleeing from Eritrea and Afghanistan on smuggling routes across the Sahara through Jordan, Egypt, and Libya and then, eventually, to Italy or Malta. 8,000 people a day -1350 in the four hours that it takes you to read these articles - will reach Europe's borders. Many will face uncertain futures in crowded camps or hostels. Many others will be deported. Many hundreds will be intercepted in the Aegean or Mediterranean, or end their journeys at the newly fortified razor wire fences erected along the borders of gateway countries like Macedonia and Hungary. Many thousands will not survive. Over a million men, women, and children were estimated to have attempted the journey to Europe over the Mediterranean in 2015. Of these, 3,770 are known to have died (Crawley et al, 2015). Of the $4.9 \mathrm{~m}$ Syrian refugees that were registered as of 2015, just 
under $2.4 \mathrm{~m}$ are aged 18 or under. Over 800,000 are younger than four years old. Over 98,000 of those children currently living in Europe's refugee camps made the journey alone or were separated from their parents on the way, either because they were killed, or because they disappeared one day and never came back, or because they could only afford one place on the boat, or inside the storage container, that would take them away (United Nations, 2015).

In addition to the refugees who have crossed one of Syria's borders, are those people whose futures arguably look bleakest of all: those who have been forced to flee their homes by the violence but have crossed no border; those who have grabbed what they can and left. Many will be caught and either murdered or imprisoned by the forces that they are running from, perhaps today or perhaps after weeks or months of fleeing across landscape that can see day time temperatures of over 40 degrees Celsius plummet to less than zero at night. Many will succumb to starvation, thirst, disease, or exposure. There are currently around $8 \mathrm{~m}$ of these internally displaced people in Syria alone. The total number of people in the world running for their lives in this way, in Syria and Iraq, the Congo, Burundi, South Sudan, Nigeria, Ukraine, Colombia and beyond currently stands at around $38 \mathrm{~m}$. The total number of people who have been forcibly displaced currently stands at just over $65 \mathrm{~m}$, which is to say 1 in every 113 human beings on Earth. This number grows by 34,000 a day. Over half are aged 18 or under (United Nations, 2015).

Meanwhile, throughout the world, economic migrants in search of a better life are seeking passage from their own countries to more prosperous ones. Around $180 \mathrm{~m}$ people did so in 2015. Many travel legally. Many others do so illegally. The illegal smuggling of migrants 
across the world's two largest trafficking routes alone - the US/Mexico border and the route from Africa to Europe - generates an annual income of $\$ 6.7 \mathrm{~b}$ for criminal organisations, much of which ends up funding the illegal trafficking of drugs and human beings for the purposes of organ harvesting or slavery. This despite border enforcement initiatives in the US that have transformed the US/Mexico border region 'into a militarized zone where the US constitution and international law are selectively applied' and in which authorities practice the 'systemic violation of the civil and human rights of border crossers and those living in border communities' (Border Network for Human Rights, 2008; p. 8). Many thousands of economic migrants seeking illegal passage into the US, the nations of Europe, and elsewhere do not survive their journeys. Many thousands more will be repatriated. Many thousands of those who make it through will live exploited, poor, and isolated lives on the margins of the societies in which they now reside.

How should individuals and governments respond to statistics such as these? The scale of the problem seems to require urgent action. But what kind of action? And by whom? Public attitudes toward immigration have changed over the past three decades, and immigration policies throughout the world, and particularly in Europe, have changed too. The 1990s and 2000s saw an increased willingness among many states to welcome immigrants and to recognise and even celebrate the diversity that increased immigration created. The relaxation of border controls among member states of the EU, for example, and the increased adoption of multiculturalist policies aimed at the recognition of minority identities in states like Britain, Holland, Denmark, and Germany formalised a growing positivity among policy makers and citizens about the economic and cultural benefits that increased migration could bring. As the EU expanded, however, and as citizens of European states 
became increasingly concerned about Islamic terrorism and other perceived external threats, enthusiasm for free movement among the original member states began to decline (Parvin, 2009). The relaxation of border controls within Europe has, according to many of Europe's citizens and governments, led to an untenable influx of migrants into the more prosperous nations. Migration on this scale, they have said, jeopardises national identity, undermines social unity, and affords unfair advantages to foreign nationals. The current refugee crisis only exacerbates these concerns, and exerts greater pressures on an already struggling international system, they suggest.

The fact that immigration has become a significant concern among citizens of liberal democratic states has thrust it to the foreground of contemporary global and domestic politics. It dominated the 2015 elections in the UK and France, for example, and is currently figuring highly in the current US Presidential campaign. It also played a profound role in motivating many British citizens to vote to leave the EU in the 2015 referendum, with concerns about immigration and a perceived lack of control over Britain's borders being among the most common reasons given for rejecting the EU. Switzerland and Poland have recently elected anti-immigration governments, the National Front in France remains strong despite their failure to make the electoral breakthroughs that many predicted, and indeed appears to be growing in popularity among French voters in the wake of recent Islamist terror attacks. British politics already looks to have shifted to the right in the wake of the referendum vote, with hostility to immigrants and racial violence showing marked increases. Immigration policies have seen significant tightening across the world, and attitudes toward cultural, ethnic, and religious diversity in many states have hardened. Belgium, France, and Holland have passed stringent laws outlawing the public wearing of certain forms of 
religious dress at the same time as strengthening their borders against non co-nationals. Similar laws look likely to be implemented in Norway, Denmark, and Austria, and have been discussed in England. If the 1990s and 2000s saw multiculturalism emerge as a dominant force among European states, the past decade has seen those same states reverse their position, calling for the strengthening of border controls and policies which emphasise unity over diversity, and prioritise opportunities for co-nationals over foreigners.

The movement of peoples across borders, and within them, is thus an issue which raises profound and enduring questions for political theory and practice. At the level of theory, it questions the demands of justice on the global and domestic stage, the character and origins of our moral obligations, and the means by which the competing interests at stake in questions concerning state sovereignty, rights, and national identity are identified and balanced. It also dramatizes a stark and enduring tension between the requirements of justice and the requirements of democracy. Many political theorists have argued that justice requires the loosening of border controls and the greater accommodation of migrants by Western liberal democratic states. But what if the expressed democratic will of the citizens of these states is to impose stricter limits on immigration and to emphasise shared values over the values of minorities, as it seems to be? Should not their democratically elected governments take this fact seriously and act on it? How should the expressed will of citizens figure in our normative theorising about migration, if at all?

The question raises at least two fundamental methodological questions about the appropriate conduct of political philosophy itself. The first concerns the extent to which normative theorising should be anchored in the lived reality of contemporary political 
practice. How far from the lived experience of real people should political theorists retreat in order to determine normative solutions to problems like the refugee crisis, people smuggling, the exploitation and death of boat people, or the lengths that the world's poor will go to in order to better their lives in another country? Some distance seems necessary. We need to inhabit a theoretical space in which we can reflect upon how the local affects the universal, what the lived experience of particular people in a particular place says, if anything, about the way we should treat all people in all places. But too much distance risks eviscerating the process of the very human experience which drives the search for answers. Deep tragedy of the kind that we see played out in the icy waters of the Mediterranean, the bombed streets of Aleppo, or the burned villages of North East Nigeria tests the veracity and limits of political philosophy. The more obvious and stark the tragedy, the more is at stake in the ongoing debate among ideal and non-ideal theorists, or among moralists and realists, about the appropriate conduct and subject matter of political theory (Valentini, 2012; Rossi \& Sleat, 2014).

The second, and connected, methodological question concerns the principal task of normative theorising. What is the central purpose of normative political theory? One answer, especially common among liberals working in the Rawlsian tradition, is that it is to determine a just distribution of scarce resources among individuals assumed to be free and equal. If this is the task of political philosophy, it is not surprising that many political philosophers have been persuaded of the case for open borders. Immigration enforcement is expensive and violates the liberal principle of equal opportunity, they have argued. It is therefore a colossal and unjust misuse of scarce public resources. The UK spent $£ 1.8 \mathrm{~b}$ on immigration enforcement last year. The US spent \$18b. On top of the money spent by 
individual member states, the 2016 budget allocated to the EU's Regional Task Force, in charge of policing the EU's external borders, patrolling Europe's oceans, and screening applicants, stands at $€ 200 \mathrm{~m}$. This, they say, is a lot of money that could and should be spent on other things more consistent with principles of social justice.

Another answer, however, is that it is an important role of normative theory to seek to protect common forms of identity, whether cultural, national, civic, or religious, and that questions of distribution cannot be disentangled from wider questions about the nature, character, and integrity of the communities within which redistribution takes place (Kymlicka, 1996; Miller, 1997). Such a view makes greater space for the need to protect the borders between groups of one kind or another, and to take seriously the importance of these communities both for justice and for the wellbeing of those who belong to them. Defenders of such a view may debate the figures involved, and the relative importance of different communities, but they tend to be more critical of the principled claim made by many cosmopolitan liberals that the protection of borders is necessarily an unjust use of scarce resources.

These methodological questions, and the diverse ways in which they have been answered by political theorists and others, at least partly explains the disconnect between the general trajectory of contemporary political philosophy and that of public opinion on matters of immigration, and also between David Miller and many of his peers on this issue. While the tide of public opinion is turning toward greater control of borders, stricter rules, and a reduction in numbers, a significant number of political theorists have gone in the opposite direction. Despite some concerns among certain social democrats and other progressive 
liberals about the challenges to egalitarian politics and social justice posed by immigration and diversity (Barry, 2001; Blake, 2013; Wellman, 2008), the burgeoning literature on the political philosophy of migration is arguably characterised by a growing agreement among many egalitarian and libertarian political philosophers on the need for the relaxation of border controls or even the abolition of all such controls (Abizadeh, 2010; Brennan, 2014; Carens, 2015). Miller's position on immigration, like his position on national identity and global justice, thus stands at odds with that of many political theorists working in the AngloAmerican tradition. He ends up in a different place because he begins in a different place: his answer to the methodological questions posed above differ from that employed by many of his peers.

Indeed, Strangers in our Midst is arguably as much a book about political philosophy, and about how to do political philosophy, as it is a book about migration. For 'strong' cosmopolitans the principal task of political philosophy is to derive regulative first principles of justice which can be justified by a process of reasoned theorising which does not, as much as possible, make reference to, or ground itself in, the lived experiences or expressed ideas of individuals in the real world (Barry, 1999; Beitz, 1979). Such experiences are bracketed off for the purposes of justifying principles on terms that all rational individuals could accept regardless of their particular experiences, ideas, or values. Feasibility constraints such as non-compliance, the expressed views of actually-existing people, the complexity introduced by contemporary global and domestic institutional regimes, and the absence of just background conditions are also put aside in order that they do not unduly clutter the search for first principles. Grand theorising of this kind tends to produce principles which are (a) universal in scope, but (b) politically unfeasible. This is not 
surprising. Principles derived in abstraction from empirical circumstances and the expressed ideals of the people involved may apply readily to the world as it currently is and may offer solutions which feed into public policy debates about problems in this world, but this would be coincidental. That that they do or do not do so does not influence their defensibility. The defensibility of such principles is judged independently of such contingent factors as what actual people currently think or how global politics is currently configured and, hence, they more often than not call for the radical reconstruction of domestic and global politics, ignore the expressed views of actual people, and reject many of the most fundamental assumptions that shape the conduct of politics in the contemporary age.

Miller's approach, on the contrary, is to seek normative principles which are at least partly grounded in lived experiences and values and which, therefore, produce outcomes which are anchored to some extent in the real world and which speak to policy debates. His aim is to question existing political and institutional arrangements, but to do so in a way that 'throws light on our predicament' instead of imagining radical and unworkable utopias (Miller, 2016). Such an approach, he believes, is both realistic and political, rather than ethical. He is not interested in making the problems associated with migration disappear by, for example, proposing a stateless world, or presupposing background conditions of perfect justice, as strong cosmopolitan thinkers are more likely to do (Miller, 2016, pp 157 - 159). He is also not primarily concerned to 'tell people how to behave' (Miller, 2016, p. 18). Instead, he seeks to resolve the questions about immigration raised by the empirical evidence through public policy and institutional reform. His is not a Rawlsian project in ideal theory but rather one which grapples with the pressures exerted by non-ideal political forces and social facts; one in which normative conclusions take seriously the expressed 
values and concerns of the people who are going to be affected by these conclusions if they were to be acted upon, in a specific empirical context at a specific moment in time.

This method has important implications. If we can agree that human experience matters to our normative theorising and, in particular, that the experiences and concerns of migrants have an important role in shaping our normative conclusions about what is at stake in this issue, then it suggests that the experiences and concerns of non-migrants should matter in our theorising too. If the process of normative theorising is appropriately influenced by the felt needs of people who exist in the world and not conducted from a standpoint of pure reason which abstracts itself from these people and their experiences, then it becomes an important task of political theory to weigh competing concerns rather than to derive abstract rules independently of them. Miller has long believed that political theorising should take more account of the values and concerns of its subjects than is customary among those who follow the Rawlsian method. In his words, justice should be for Earthlings (Miller, 2013). Hence, for Miller, the fact that many people in the world claim to have a national identity that at least partly shapes their sense of self is important and carries some normative weight. Similarly, the fact that many people in the world express a concern about migration also carries normative weight and needs to be considered. The fact that arguments for open borders are very unpopular among many citizens of liberal democratic states does not, for Miller, represent merely a practical problem of feasibility (although it does do this). It is undermines their philosophical persuasiveness. Normative theories must work, or at least have some chance of working, in the world as it is currently configured, given the way people currently act. In a democratic state, immigration policies must be acceptable to their citizens. Justice for Miller needs to be realistic in the sense that it needs 
to accord with overarching, widespread ideas shared among the people to whom it will apply as well as being practically achievable.

Does Miller's approach lack ambition? Certainly, on the face of it 'strong' cosmopolitanism appears to embody a courage that the Miller's 'weak' cosmopolitanism seems to lack: a determination to tackle the biggest, most fundamental questions of all and, often, to recommend solutions which reject popular opinion and contemporary political practice in favour of the radical reconfiguration of our politics and the assumptions upon which they are based. But while this approach may appear courageous, it actually ducks the issue. Bracketing off all the messy and complex aspects of a problem actually makes the process of normative theorising about that problem easier, not harder. It removes, or radically alters or diminishes, the problem. So while some political theorists may be satisfied with a solution grounded in the radical recalibration of global political institutions and processes, governments and policy makers actually tasked with the responsibility of dealing with the issue in this world at this time will not. In a complex world characterised by domestic and international pressures, in which policy decisions need to be negotiated and implemented in a process involving countless state and non-state actors of different kinds and of different sizes with different jurisdictions, in a wide political context defined by long-standing multilateral agreements, formal and informal relations, and a rigid system of international law administered by countless large and small institutions throughout the world, the suggestion that we solve the issue of migration by, for example, removing all borders and establishing institutions which support the global free movement of peoples seems at best unhelpful and at worst self-indulgent. 
Miller's approach is to occupy a position sufficiently removed from lived reality to allow the practice of normative theorising to take place, but not so removed as to uncouple this practice from the real world entirely. For some, he will admit too much of the real world. These people are likely to be troubled by Miller's rejection of open borders, his defence of compatriot partiality, his claim that a state's immigration policy should be at least partly shaped by the democratic will of the people of that state and not derived entirely from first principles, and his claim that economic migrants cannot claim an automatic right to admission on the basis of justice. Others will think that he admits too little. These people are more likely to dislike Miller's call for a much stronger commitment to accommodating refugees and to respecting the basic human rights of would-be immigrants than is consistent with the overarching tenor of discussions among many governments and their publics at the present time. Miller's Strangers in our Midst will therefore prove controversial to almost everyone who reads it, inside and outside of academia. This is only fitting. As the pieces in this special section of CRISPP show, Miller's attempt to produce normative conclusions which are anchored at least partly in the actual views that real people have, and which seek to provide philosophically rigorous solutions to concrete problems experienced by actually-existing states poses a challenge to both widespread public opinion and also to many political philosophers working in the Anglo-American tradition. In doing so, it forces political philosophers to think again not only about the issue of migration, but about the nature and purpose of political philosophy itself. ${ }^{* *}$

Dr Phil Parvin is a Senior Lecturer in Politics at Loughborough University. 
Bibliography

Abizadeh, A. (2010) 'Closed borders, human rights, and democratic legitimation', in D. Hollebach (ed.) Driven From Home: Human Rights and the New Realities of Forced Immigration (Washington DC: Georgetown University Press), pp. 147 - 167.

Barry, B. (1999) 'Statism and Nationalism: A Cosmopolitan critique', in I. Shapiro \& L. Brilmeyer (eds) Global Justice (New York: New York University Press).

(2001) Culture \& Equality: An Egalitarian Critique of Multiculturalism

(Cambridge: Polity)

Beitz, C. (1979) Political Theory and International Relations (Princeton, NJ: Princeton University Press).

Blake, M. (2013) 'Immigration, jurisdiction, and exclusion', Philosophy \& Public Affairs 41/2, pp. $103-130$.

Crawley, H., Duvell, F., Sigona, N., McMahon, S. and Jones, K. (2016) Unpacking a rapidly changing scenario: migration ows, routes and trajectories across the Mediterranean http://www.medmig.info/research-brief-01-unpacking-a- rapidly-changing-scenario/

Miller, D. (1997) On Nationality (Oxford: Oxford University Press).

(2013) Justice for Earthlings: Essays in Political Philosophy (Cambridge:

Cambridge University Press).

(2016) Strangers in our Midst (Cambridge, MA: Harvard University Press).

Parvin, P. (2008) 'What's special about culture? Identity, autonomy, and public reason',

Critical Review of International, Social, and Political Philosophy 11/3, pp. $315-333$.

(2009) 'Identity and integration in an international context: Problems and ambiguities in the new politics of multiculturalism', Political Studies Review $7 / 3$.

Pogge, T. (2002) World Poverty and Human Rights: Cosmopolitan Responsibilities and Reforms (Cambridge: Polity)

Rossi, E. \& M. Sleat (2014) 'Realism in normative political theory', Philosophy Compass 9/10, pp. 689-701.

United Nations (2015) 'Global forced displacement for 2015 on track to to break all records - topping 60 million', UN News Centre report. Available:

http://www.un.org/apps/news/story.asp?NewsID=52859\#.VxZk70vCqkh

UNHCR (2016) Global Trends: 2015 (United Nations) 
Kymlicka, W. (1996) Multicultural Citizenship: A Liberal Theory of Minority Rights (Oxford: Oxford University Press).

Wellman, C. (2008) 'Immigration and freedom of association', Ethics 119, pp. $109-141$.

Valentini, L. (2012) 'Ideal and non-ideal theory', Philosophy Compass 7/9, pp. 654-664.

\footnotetext{
*Email: p.parvin@lboro.ac.uk

${ }^{* *}$ The essays in this special section of CRISPP began life as papers presented at two separate events devoted to discussing David Miller's latest contribution to the debate about immigration and political theory. The first was a roundtable session at the 2016 Britain and Ireland Association for Political Thought conference held at St Catherine's College, Oxford, $8^{\text {th }}$ January 2016. The session was Chaired by myself, and comprised shorter versions of the papers included in this volume by David Miller, Sarah Fine, Chandran Kukathas, and David Owen. The second event was a workshop held at the Institute for Philosophy, Hamburg University, $18^{\text {th }}$ March 2016, organised by Thomas Schramme and Christine Straehl, comprising papers by David Miller, David Owen, Oliviero Angeli, Eszter Kollar, and Christine Straehl. I should like to thank all these contributors, and those who provided anonymous peer review, for their assistance in organising this CRISPP special section. I should also like to thank Richard Bellamy for the initial invitation, and Christine Straehl for co-organising.
} 